\title{
Educational Environment, Ethnocentrism, and Prejudice Towards Indonesian Chinese
}

\author{
Baidi Bukhori \\ Universitas Islam Negeri Walisongo Semarang
}

\begin{abstract}
Inter-ethnic prejudice is one of the problems faced by multi ethnic nations, including Indonesia. It does not only bring positive impacts in social interactions, but can also lead to social conflicts. To prevent the conflicts, an understanding of prejudice is required. So, the purposes of this study were: (1) To examine the effect of different educational environment on prejudice towards Chinese ethnic groups by controlling ethnocentrism; (2) To examine the influence of ethnocentrism on prejudice towards Chinese ethnic groups by controlling educational environments. Population in this study $(N=200)$ was non-Chinese students in Semarang. Sampling was done by applying a stratified sampling technique. Data were collected using the scales for both prejudice towards Chinese ethnic groups and ethnocentrism. Then, a statistical method using covariance analysis was used to analyze the data. Results revealed a difference in prejudice towards Chinese ethnic groups between students who studied at a college having Chinese students and those at a college having no Chinese students by controlling ethnocentrism. Besides, there was a significant ethnocentric role in prejudice towards Chinese ethnic groups by controlling educational environments.
\end{abstract}

Keywords: prejudice, Chinese ethnic groups, educational environment, ethnocentrism

Prasangka antar-etnik merupakan salah satu permasalahan yang dihadapi oleh bangsa multi-etnik, seperti Indonesia. Tanpa bermaksud menafikan dampak positif adanya prasangka antar-etnik dalam interaksi sosial, prasangka antar-etnik dapat menyebabkan konflik sosial. Untuk mencegah terjadinya konflik sosial tersebut maka pemahaman tentang prasangka sangat diperlukan. Tujuan studi ini adalah: (1) Menguji pengaruh perbedaan lingkungan pendidikan terhadap prasangka pada etnik Tionghoa dengan mengendalikan etnosentrisme; (2) Menguji peran etnosentrisme dalam prasangka pada etnik Tionghoa dengan mengendalikan lingkungan pendidikan. Populasi dalam penelitian $(N=200)$ ini adalah mahasiswa yang beretnik non-Tionghoa di Kota Semarang. Pengambilan sampel dilakukan dengan teknik stratified sampling. Metode pengumpulan data yang digunakan adalah skala prasangka pada etnik Tionghoa dan skala etnosentrisme. Metode analisis data yang digunakan adalah metode statistik dengan teknik analisis kovarians. Hasil menunjukkan terdapat perbedaan prasangka pada etnik Tionghoa antara mahasiswa perguruan tinggi yang memiliki mahasiswa Tionghoa dan mahasiswa perguruan tinggi yang tidak memiliki mahasiswa Tionghoa dengan mengendalikan etnosentrisme. Selain itu terdapat peran etnosentrisme yang signifikan dalam prasangka pada etnik Tionghoa dengan mengendalikan lingkungan pendidikan.

Kata kunci: prasangka, etnik Tionghoa, lingkungan pendidikan, etnosentrisme.

Indonesia is a nation with diverse natural ecosystems, cultures, customs, languages, religions and ethnicities. These diversities are precious resources if they are managed correctly, but if mismanagement occurs, it can cause either social conflicts or

Correspondence concerning this article should be addressed to Baidi Bukhori, Faculty of Psychology and Health, State Islamic University (UIN) Walisongo Semarang, Jalan Prof. Dr. Hamka (Kampus III), Ngaliyan, Semarang, Indonesia. Email: baidi_bukhori@walisongo.ac.id conflicts between cultural or ethnic groups involving their group identity, such as ethnic identity. Social conflicts motivated by ethnic differences in Indonesia include: (1) the conflict between Chinese ethnic groups and non-Chinese ethnic groups. This is apparent during the riots in May 1998, which led to the looting of Chinese ethnic's properties, violence and sexual harassment of Chinese women (Nyman, 2006); and (2) the conflict of Dayak and Madura 
tribes that occurred in Sampit resulting in the deaths of hundreds of people (Nooteboom, 2015).

Inter-ethnic conflicts occur due to the fundamental differences of identity belonging to the ethnic groups that result in such feeling of in-group or outgroup in the process of their social interactions which leads to prejudice. Moreover, inter-ethnic prejudice itself can be a trigger for social conflicts (Hadjar, 2010).

Inter-ethnic prejudice is an attitude (usually negative attitude) against certain ethnic groups, solely based on their affiliation with the group (Baron \& Byrne, 2006). In line with this definition, there are three aspects of prejudice. First, it is preserving traditional individualistic values with believing that minorities have accepted discrimination while they actually should not receive this conduct at all. Second, it is an attitude of exaggerating cultural differences between the majority and minority groups (e.g. in terms of values, religion, and languages). Third, it is denying positive emotional responses to the members of out-group (Pettigrew \& Meertens, 1995).

According to Baron and Byrne (2006), negative actions based on ethnic prejudice have decreased. However, it does not mean that extreme expression is totally lost because even dramatic criminal cases based on ethnic prejudice tend to persist. One of the conflicts and racial discrimination was the tragedy of May in 1998. The riots occurred on 13-15 May 1998 and hit most major cities in Indonesia, especially Jakarta. This incident was actually a calamity for Indonesian people, particularly for the Chinese ethnic groups (Afif, 2012).

Inter-ethnic disputes, particularly between Chinese and non-Chinese ethnic groups are generally triggered by injustice. Statistical data revealed by the socioeconomic observers stated that Chinese descents dominated $50 \%$ of the Indonesian economy (100 USD), although their number was only $4 \%$ of the total population in Indonesia (Nuqul, 2002). This inequality, thus, has caused such prejudice from certain ethnic groups toward Chinese ethnic descents.

The economic disparity between Chinese and non-Chinese ethnic groups occurred as a socio-political impact of the New Order Government. At the time, Chinese ethnic groups were given a freedom to control the economic sector, but they were restricted and even treated discriminatively in the public sphere. This restriction led them to fully pursue the economic sector which was very difficult to be competed by other ethnic groups. As a result, Chi- nese ethnic groups became the 'scapegoat' when economic problems occurred in the society (Setiono, 2008).

In addition to economic factors, prejudice towards Chinese ethnic groups is also based on several aspects. Sartono (1995) stated that non-Chinese people still have negative views towards Chinese people, either from social, religious, marital, cultural, or educational perspectives. For example, Taoism and Confucianism are the religions of Chinese ethnic groups as well as their ancestral religion, in contrast to the religion adopted by the majority of Indonesian population. This case leads to differences in values or norms.

In addition, prejudice is a social psychological phenomenon. It is mainly influenced by social interactions with the object of prejudice, either originating from the internal individual or the outside individual (Hadjar, 2010). The internal factors which influence prejudices to others are namely: authoritarian personality (Asbrock, Christ, Duckitt, \& Sibley, 2012; Johnson et al., 2011), introverted personality (Hadjar, 2010), social dominance orientation (Costello \& Hodson, 2011; Ho et al., 2012), religious orientation (Bukhori, 2011), fundamentalism (Bukhori, 2012; Bukhori \& Hassan, 2016; Putra \& Wongkaren, 2010), and ethnocentrism (Bizumic \& Duckitt, 2007). In contrast, the external factors affecting prejudice to the others are namely: social identity (Ali, Indrawati, \& Masykur, 2010; Barlow, Louis, \& Terry, 2010; Bukhori \& Hassan, 2016), level of education (Iglic, 2010), interactions (Binder et al., 2009) and school or college milieu (Hadjar, 2010; Raihani, 2011).

Due to the many influential factors of prejudice, this study was only limited to two factors, namely educational environments and ethnocentrism. Ethnocentrism is a representation of the internal factors, while an educational environment is a representation of the external factors.

According to Hadjar (2010), prejudice is a phenomenon arising from inter-group relations. In the context of educational environments, prejudice varies due to differences in providing students with opportunities to interact with different groups or ethnicities. The more extensive opportunities the students get to interact with other ethnic groups, the lower the students' prejudice towards them. By interacting, the students will get more objective information about other ethnic groups so that it will reduce the possibility of having negative stereotypes. In addition, the intensity of interactions between heterogeneous individuals in an educational envi- 
ronment (a campus) would affect the feeling of liking between them. The higher the intensity of interactions between them, the greater the chances of developing the feeling of liking. In contrast, the campus environment that does not allow an interaction between individuals from different cultural backgrounds will reduce the feelings of liking toward other groups and even trigger prejudice. Hadjar's study (2010) showed that there was a difference in prejudice towards other religious groups among Muslim students in different educational environments. Muslim students studied in homogenous educational environments like Madrasah Aliyah (Islamic High School) had a higher level of prejudice than those who studied in heterogeneous educational environments like Secular High School. Indeed, Bukhori's (2013) study showed that Muslim students in a homogeneous educational environment had a lower level of tolerance than the students in a heterogeneous educational environment (a secular college).

In addition to educational environments, prejudice is also affected by ethnocentrism. According to Brewer and Brown (1998), ethnocentrism is one of the means to support social prejudice. It can be interpreted as a view of a group claiming that his/her group is of higher status than the others' and he or she judges other groups based on his/her group perspective including assuming that other groups are lower and less valuable (Negy, Shreve, Jensen, \& Uddin, 2003). It is difficult for someone with a high ethnocentrism to remove him/herself from his/her own perspective. He or she can only understand something based on his/her perspective, while he or she cannot understand others' behaviors based on their backgrounds (Zatrow, 1989). Therefore, Altemeyer's (2003) and Negy et al.'s researches showed that ethnocentrism was associated with prejudice.

Bizumic, Duckitt, Popadic, Dru, and Krauss (2009) reveal that there are six expressions of ethnocentrism, consisting of four expressions of inter-group and two of intra-group. Inter-group ethnocentrism is a belief or a feeling that one's ethnic or cultural group is more important than the other groups. This expression includes four aspects, namely: (1) Preference is a tendency to prefer, like preferring to choose one's ethnic or cultural group rather than the others; (2) Superiority is a belief that one's culture or ethnic group is better or superior than the others; (3) Purity is a desire to preserve the "purity" of one's culture or ethnic group; (4) Exploitation is a belief that the interest of one's cultural or ethnic group is always the most concerned. Hence, if someone pursues this expression, he or she would give a disadvantage to other groups.

Moreover, intra-group ethnocentrism is a belief that one's ethnic or cultural group is more important than its members. This expression includes two points: (1) Group cohesion is a belief that one's culture or ethnic group should be highly integrated, cooperative and united; (2) Devotion is a strong dedication and loyalty to one's culture or ethnic group, as well as a willingness to sacrifice and to suffer for the sake of the group.

Based on the aforementioned explanation, it is understood that prejudice towards other ethnic groups is not only influenced by educational environments, but also ethnocentrism. Furthermore, due to the complex phenomenon of prejudice towards other ethnic groups, the influence of a certain factor towards prejudice is also related to the other factors (Hadjar, 2010).

Therefore, the researcher suggested two hypotheses, namely: (1) There would be a difference in prejudice towards Chinese ethnic groups between university students who studied at a college having Chinese students and those who studied at a college having no Chinese students by controlling ethnocentrism; (2) ethnocentrism would significantly influence prejudice towards Chinese ethnic groups by controlling educational environments.

\section{Method}

This study is a quantitative research with one criterium variable, namely prejudice towards Chinese ethnic groups, as well as two predictor variables, namely educational environments and ethnocentrism.

Prejudice towards Chinese ethnic groups is a negative judgment towards Chinese ethnic groups merely due to their ethnicity without considering their personal characteristics. There are three aspects of prejudice towards Chinese ethnic groups, namely: (a) Preserving the traditional individualistic values coincided with a belief that Chinese ethnic groups have accepted inappropriate behaviors; (b) Exaggerating cultural differences between non-Chinese ethnic groups and Chinese ethnic groups; (c) Denying any positive emotional responses towards Chinese ethnic groups (Pettigrew \& Meertens, 1995). The level of prejudice towards Chinese ethnic groups is reflected from participants' scale scores. A higher 
score indicates that prejudice is at a higher level, while a lower score indicates that the prejudice is at a lower level.

Educational environments are everything around the universities where people study. In this case, an educational environment is divided into two, namely: a college having Chinese students and a college having no Chinese students.

Ethnocentrism is a feeling or an assumption that one's own ethnic group is the most important group and becomes the most center of attention. It consists of two aspects, namely: inter-group and intra-group ethnocentrism. The expression of inter-group ethnocentrism includes four aspects: (1) preference; (2) superiority; (3) purity; and (4) exploitation. On the other hand, the intra-group expression of ethnocentrism includes two aspects. The first is cohesion and the second is devotion (Bizumic et al., 2009). The level of ethnocentrism is reflected from participants' scale scores. A higher score indicates that the prejudice is at a higher level, while a lower score indicates that the prejudice is at a lower level.

The population in this study was non-Chinese students in Semarang, who through a stratified sampling technique were divided into group levels of population according to certain characteristics such as college origin and the enrollment year of students (in semester). Then the authors employed a simple random sampling in each level of the population. Based on these techniques, 200 students were obtained as participants, consisting of 100 students of the Faculty of Da'wah and Communication of Walisongo State Islamic University Semarang and 100 non-Chinese students of the Faculty of Psychology of Soegijapranata Catholic University Semarang.

Data were collected using a psychological scale method, which includes:

\section{Scale of Prejudice Towards Chinese Ethnic Groups}

The variable of prejudice towards Chinese ethnic groups was measured using the scale of prejudice towards Chinese ethnic groups. The items were set up based on three aspects of subtle prejudice by Pettigrew and Meertens (1995), namely: (1) Preserving the traditional individualistic values coincided with a belief that Chinese ethnic groups has accepted inappropriate behaviors; (2) Exaggerating cultural differences between non-Chinese ethnic groups and Chinese ethnic groups; (3) Denying any positive emotional responses towards Chinese ethnic groups.
The scale of prejudice towards Chinese ethnic groups consists of 17 items. The coefficient of reliability of the scale of prejudice towards Chinese ethnic groups was .827.

\section{Ethnocentrism Scale}

The ethnocentrism variable was measured using a scale of ethnocentrism. The items were arranged based on Bizumic et al.'s opinion (2009) that ethnocentrism consists of two dimensions, namely intergroup ethnocentrism and intra-group ethnocentrism. The dimensions of inter-group ethnocentrism consist of: (1) preference; (2) superiority; (3) purity; and (4) exploitation. On the other hand, the dimensions of intra-group ethnocentrism consist of: (1) group cohesion; and (2) devotion. The ethnocentrism scale consists of 11 items. The coefficient of reliability of the scale of ethnocentrism was .823.

A statistical method using covariance analysis utilizing the SPSS program, version 16.0. was used to analyse the data.

\section{Results}

After conducting statistical analysis using covariance analysis, it was found that the significant value or the probability for the variable of educational environments was .006; it was less than the significance level (.05). Therefore, it can be concluded that a hypothesis explaining that there was a difference in prejudice towards Chinese ethnic groups between university students who studied at a college having Chinese students and those who studied at a college having no Chinese students by controlling ethnocentrism could be accepted.

Based on the mean score differences between students in two different colleges namely, the Faculty of Da'wah and Communication of Walisongo State Islamic University and the Faculty of Psychology of Soegijapranata Catholic University, it was found that the level of prejudice towards Chinese ethnic groups of the students at the Faculty of Da'wah and Communication was 42.0300. This was higher than the level of prejudice of the students at the Faculty of Psychology of Soegijapranata Catholic University which was 39.8500 .

In addition, data showed that the significant value or the probability for the variable of ethnocentrism was 0.000 . As the value for the variable of ethnocentrism (.000) was smaller than the significance 
level (.05), it can be concluded that the hypothesis explaining that ethnocentrism had a significant influence on prejudice towards Chinese ethnic groups by controlling educational environments, could be accepted. In other words, the higher the ethnocentrism of a certain group, the higher their prejudice towards Chinese students. Conversely, the lower the ethnocentrism, the lower their prejudice towards Chinese students.

\section{Discussion}

Data analysis showed that there was a difference in prejudice towards Chinese ethnic groups between university students studied at a college having Chinese students and a college having no Chinese students by controlling ethnocentrism. The students from the university having no Chinese students (the Faculty of Da'wah and Communication of Walisongo State Islamic University) had a higher prejudice towards Chinese ethnic groups than the students from the university having Chinese students (the Faculty of Psychology of Soegijapranata Catholic University/ UNIKA Soegijapranata).

The finding supported the results of Hadjar's study (2010) which indicated that there was a difference in prejudice towards other religious groups among Muslim students with different educational environments. For those who studied in homogenous educational environments like Madrasah Aliyah (Islamic High School), they had a higher level of prejudice than those who studied in heterogeneous educational environments like Secular High School.

This phenomenon is understandable because a homogenous campus environment does not allow students to interact with other individuals from different cultural backgrounds. As a result, a feeling of liking towards other groups does not grow naturally causing prejudice to appear among them. This situation also happened to the students of the Faculty of Da'wah and Communication of Walisongo State Islamic University that had only Muslim students with no Chinese students. In this campus, the students did not have an opportunity to interact with Chinese ethnic groups due to the homogeneity of the students. This condition made them have no positive feelings towards Chinese ethnic groups because there was no social bond unifying between the students and Chinese ethnic groups. Consequently, they had the feeling of in-group for their own ethnic group while had the feeling of out-group for
Chinese ethnic groups. This made the students' social affection become more favorable towards their own groups rather than towards other ethnic groups.

In contrast, heterogeneous educational environments, such as UNIKA Soegijapranata that had students from diverse ethnicities and religions, provided the same rights and equal opportunities to students. In this campus, the students were involved together in learning and social activities even cooperating without discriminating their cultural backgrounds. Therefore, this encourages positive attitudes towards different groups (Hawley, 1992).

Furthermore, positive attitudes also emerge because they cooperate within the same social organization, so they are bounded in a certain social group and they even develop togetherness. This togetherness becomes an important principal for their group identity, and it develops to become the norm of the group. The stronger the norm is created among them, the more powerful the group members will identify themselves to their group. Self identify to the group, then, encourages the emergence of positive assessments to its members (Hadjar, 2010).

Based on the aforementioned analysis of data, it was also found that by controlling educational environments, there was an ethnocentric influence on prejudice towards Chinese ethnic groups. This influence is in line with the opinion of Brewer and Brown (1998) that ethnocentrism is one of the means to support social prejudice. Indeed, research by Negy et al. (2003), Altemeyer (2003), and Bizumic and Duckitt (2007) showed that ethnocentrism was closely related to prejudice.

Regarding to this issue, Coleman and Cressey (1984) argued that people from a certain ethnic group tends to see their culture as the best. In line with this opinion, Baron and Byrne (2006) stated that intergroup relations generally occur because a certain group tends to see themselves as the center of everything. As a result, in-group favoritism emerges and they consider it as a base for measuring things outside their group. This trend is called ethnocentrism.

In this case, people with high ethnocentrism believe that their in-group is the best, superior and holds the best value, whereas other groups are disgraceful, immoral, inferior, weak, doubtful and criminal (Brewer as cited in Taylor, Peplau, \& Sears, 2000). These kinds of feelings and behaviors actually generate the ideology of an exclusive group. Further, the feeling of "superior" also triggers such kind of prejudice (Singgih, 1993). In addition, people 
with high ethnocentrism have more interactions with their own group members as such, rather than with people outside their group. This results in disharmonious communication and social interactions. Finally, it leads to prejudice toward other groups and cultures.

\section{Limitations of the Study}

This study only examines two variables that influence prejudice towards Chinese ethnic groups, namely educational environments and ethnocentrism, while there are still many other factors that influence prejudice towards Chinese ethnic groups.

Technically, the researcher did not collect data directly, but was assisted by other lecturers. This might result in differences in the quality of answers given by the participants.

\section{Conclusion and Recommendation}

Despite its limitations, the study has several practical contributions. The results revealed that university students who studied at a college with Chinese students had a lower level of prejudice towards Chinese ethnic groups than those who studied at a college without having Chinese students. This study triggers a cognitive exercise of the faculty of ethnic based universities to apply nonconventional policies in recruiting students. They should be aware of the value of multicultural activities which may increase harmony and reduce cultural isolation among students. Moreover, university should encourage students to engage with Chinese ethnic groups in learning, organization, and social activities.

Moreover, educators should encourage activities which involve students from diverse ethnic backgrounds to work together in non-competitive and engaging activities, such as goodwill trips and social services. Through these activities, a better understanding of other ethnic groups will be built. In addition, these interactions will reduce the in-group and out-group feelings among the students. The activities will avoid any stereotypes, group exclusiveness, and ethnocentrism. Future research should explore the impact of students' backgrounds and religious orientations. By considering these variables, the influence of educational environments on prejudice can be clearly understood. Finally, prejudices to other groups, particularly against Chinese ethnic groups, will be reduced.

\section{References}

Afif, A. (2012). Identitas Tionghoa Muslim Indonesia: Pergulatan mencari jati diri. Depok: Kepik.

Ali, R., Indrawati, I. S., \& Masykur, A. M. (2010). Hubungan antara identitas etnik dengan prasangka terhadap etnik Tolaki pada mahasiswa Muna di Universitas Haluoleo Kendari Sulawesi Tenggara. Jurnal Psikologi UNDIP, 7, 18-26.

Altemeyer, B. (2003). Why do religious fundamentalists tend to be prejudiced? The International Journal for the Psychology of Religion, 13(1), 17-28.

Asbrock, F., Christ, O., Duckitt, J., \& Sibley, C. G. (2012). Differential effects of intergroup contact for authoritarians and social dominators: A dual process model perspective. Personality and Social Psychology Bulletin, 38(4), 477-490. http://dx.doi. org/10.1177/0146167211429747.

Barlow, F. K., Louis, W. R., \& Terry, D. J. (2010). Minority report: Social identity, cognitions of rejection and intergroup anxiety predicting prejudice from one racially marginalized group towards another. European Journal of Social Psychology, 40, 805-818.

Baron, R. A., \& Byrne, D. (2006). Psikologi sosial. Jakarta: Erlangga.

Binder, J., Zagefka, H., Brown, R., Funke, F., Kessler, T., Mummendey, A., ... Leyens, J. P. (2009). Does contact reduce prejudice or does prejudice reduce contact? A longitudinal test of the contact hypothesis among majority and minority groups in three European countries. Journal of Personality and Social Psychology, 96(4), 843-856. http://dx.doi.org/10.1037/a0013470.

Bizumic, B., \& Duckitt, J. (2007). Varieties of group self-centeredness and dislike of the specific other. Basic and Applied Social Psychology, 29, 195-202.

Bizumic, B., Duckitt, J., Popadic, D., Dru, V., \& Krauss, S. W. (2009). A reconceptualization of ethnocentrism. European Journal of Social Psychology, 39, 871-899.

Brewer, M. B., \& Brown, R. J. (1998). "Intergroup relations". In D. T. Gilbert, S. T. Fiske, \& O. Lindzey (Eds.), The handbook of social psychology. New York: McGraw Hill.

Bukhori, B., \& Hassan, Z. (2016). Tolerance model of Muslim students for Christians in Indonesia. Man In India, 96(6), 1793-1812.

Bukhori, B. (2011). Meta-analisis hubungan orientasi religius dengan prasangka rasial. Jurnal At-Taqaddum, 3(1), 105-123. 
Bukhori, B. (2012). Toleransi terhadap umat Kristiani ditinjau dari fundamentalisme agama dan kontrol diri: Studi pada jamaah majelis taklim di Kota Semarang (Unpublished research report). Lembaga Penelitian IAIN Walisongo, Semarang.

Bukhori, B. (2013). Model toleransi mahasiswa Muslim terhadap umat Kristiani (Unpublished dissertation). Program Doktor Psikologi Fakultas Psikologi Universitas Gadjah Mada.

Coleman, J., \& Cressey, D. (1984). Social problem. New York: Harper \& Row.

Costello, K. \& Hodson, G. (2011). Social dominancebased threat reactions to immigrants in need of assistance. European Journal of Social Psychology, 41(2), 220-231.

Hadjar, I. (2010). Prasangka keagamaan. Semarang: Walisongo Press.

Hawley, W. D. (1992). School desegregation. In M.C. Alkin (Ed.), Encyclopedia of educational research. New York: Simon \& Schuster Macmillan.

Ho, A. K., Sidanius, J., Pratto, F., Levin, S., Thomsen, L., Kteily, N., \& Sheehy-Skeffington, J. (2012). Social dominance orientation: Revisiting the structure and function of a variable predicting social and political attitudes. Personality and Social Psychology Bulletin, 38, 583-606. http://dx.doi. org/10.1177/ 0146167211432765.

Iglic, H. (2010). Voluntary associations and tolerance: An ambiguous relationship. American Behavioral Scientist, 53(5), 717-736. http://dx.doi.org/10.11 77/0002764209-350834.

Johnson, M. K., Rowatt, W. C., Barnard-Brak, L. M., Patock-Peckham, J.A., LaBouff, J. P., \& Carlisle, R. D. (2011). A mediational analysis of the role of right-wing authoritarianism and religious fundamentalism in the religiosity-prejudice link. Personality and Individual Differences, 50(6), 851-856.
Negy, C., Shreve, T. L., Jensen, B. J., \& Uddin, N. (2003). Ethnic identity, self-esteem, and ethnocentrism: A study of social identity versus multicultural theory of development. Cultural Diversity and Ethnic Minority Psychology, 9(4), 333-344.

Nooteboom, G. (2015). Forgotten people: Poverty, risk and social security in Indonesia: The case of the Madurese. Leiden: Brill.

Nuqul, F. L. (2002). Hubungan antara religiusitas dengan prasangka (Unpublished thesis). Yogyakarta: Program Pascasarjana Universitas Gadjah Mada.

Nyman, M. (2006). Democratising Indonesia: The challenges of civil society in the era of reformasi. Copenhagen: NIAS Press.

Pettigrew, T. F., \& Meertens, R. W. (1995). Subtle and blatant prejudice in Western Europe. European Journal of Social Psychology, 25, 57-75.

Putra, I. E., \& Wongkaren, Z. A. (2010). Konstruksi skala fundamentalisme Islam di Indonesia. Jurnal Psikobuana, 1, 151-161.

Raihani, R. (2011). A whole-school approach: A proposal for education for tolerance in Indonesia. Theory and Research in Education, 9(1), 23-39.

Sartono, E. K. E. (1995). Beberapa faktor penghambat dan pendorong dalam memantapkan integritas nasional (Unpublished thesis). Yogyakarta: Pascasarjana Universitas Gadjah Mada.

Setiono, B. G. (2008). Tionghoa dalam pusaran politik: Mengungkap fakta sejarah tersembunyi orang Tionghoa di Indonesia. Jakarta: TransMedia.

Singgih, G. (1993). Idea umat terpilih dalam Perjanjian Lama. Yogyakarta: Pustaka Pelajar.

Taylor, S. E., Peplau, L. E., \& Sears, D. O. (2000). Social psychology. Upper Saddle River: Prentice Hall.

Zatrow, C. (1989). Understanding human behavior and the social environment. Chicago: Nelson Hall. 